\title{
Collaborative Networking for the Development of Quality in Education at University Level
}

\author{
Anni Rytkönen ${ }^{1}$ and Taina Kaivola ${ }^{2}$ \\ ${ }^{1}$ University of Helsinki, Educational Centre for ICT, P.O. Box 53, FIN-00014 \\ University of Helsinki, Finland \\ ${ }^{2}$ University of Helsinki, Faculty of Science, P.O. Box 68, FIN-00014 \\ University of Helsinki, Finland \\ \{Anni.Rytkonen, Taina.Kaivola\}@Helsinki.FI
}

\begin{abstract}
At the University of Helsinki there are two collaborative networks of expertise leading and supporting the development of teaching: the senior lecturers in university pedagogy and the e-learning specialist network. Both networks are based on the guidelines in the university Programme for the development of teaching and studies for the strategy period 2007-2009. The strategic goals, organization and working methods of these two networks are described as examples of overall quality improvement through competence development of the teaching personnel. The paper contributes also to the evaluation of actual, perceived development at the end of the strategy period. The best practices of these networks are summarized as ideal structures supporting the continuous educational development work at universities.
\end{abstract}

Keywords: Educational Development, Higher Education, E-learning, University Pedagogy, Collaboration, Collaborative Networking, Peer Networking.

\section{Introduction and Strategic Grounds}

During the last years, emphasis of quality in teaching, learning outcomes and student achievement in higher education has increased. This is due to several reasons, of which meeting the needs of trends and phenomena of the modern information society is among the most important ones. At the University of Helsinki, the strong emphasis on teaching and support of development of pedagogical skills of the academic teaching personnel raises from strategic grounds $[3,6]$. One of the most visible decisions of this emphasis is the establishment of a network of pedagogical senior lecturers, which form the core of personnel developers at the university. As team members with the senior lecturers there are e-learning specialists, who similarly with the senior lecturers form their own university-wide network of expertise.

University of Helsinki is a research-based university, among the biggest multidisciplinary universities in Northern Europe. The university concentrates on high quality research covering a wide range of academic fields [2]. The 11 faculties at the University of Helsinki are located on four campus areas in the city and suburban area of Helsinki. Both senior lecturers in university pedagogy and e-learning specialists are located distributed on all campuses, which makes networking and collaboration challenging at the 
university level. To find out the needs, methods and partners for collaboration in a peer network of expertise, a survey on the e-learning specialist work was conducted.

The quality of teaching and learning has a significant role at the University of Helsinki. For example, the university enhances the personnel's pedagogical skills by providing personnel training in university pedagogy. In practice, the responsibility of this task rests predominantly on the two specialist networks.

"The pool of university lectureships in higher education will be restructured so that each faculty will be allocated one professorship from this pool to support the development of teaching. The Academic Affairs Committee will prepare a procedure whereby the pool resources and the competence of the post holders can be used for supporting the development of teaching as efficiently and permanently as possible."

"Faculties and departments will work as teams to plan the production processes of online teaching. The faculties will implement online teaching more efficiently, and their educational technology advisors will support and participate in cooperation across faculty and university boundaries. " [3, pages 93 and 96]

In this paper, possibilities and ideals in structures and methods for organised and goal-oriented collaboration through coordinated networking are discussed. First, working methods and duties of both specialist networks are explained. Structures and methods for goal-oriented collaboration, based on survey material, are presented, and finally, some future perspectives concerning the development of the structures for collaboration in and between these kinds of specialized networks are discussed.

\section{Networks Supporting Educational Development}

\subsection{The E-Learning Specialist Network}

The e-learning specialist network consists of specialists in subfields of educational technology and e-learning. They are located on the campuses in the faculties and departments, in both full-time and part-time positions with duties concerning pedagogical cases of the use of web-based tools and educational technology.

Because further information on tasks, needs and work loads of the network members was needed, a survey by means of a web-based questionnaire was conducted. With the survey results, the overall situation on e-learning support at the university level could also be evaluated. Based on the survey, the e-learning specialists at the University of Helsinki can be profiled into two main types: 1) full-time support, planning and development, typically at the faculty level, collaborating in the same team with other educational developers and 2) support at the departments, provided full- or part-time.

The results of the survey emphasize the importance of having e-learning specialists at the faculty level, and the role of knowledge development through networking for all e-learning specialists. The main duties of the e-learning specialists include planning and developmental duties. They use time also for own knowledge development, studies and personnel training, peer activities, such as networking. Own research is non-typical for both faculty and departmental specialists. Tasks more typical to elearning specialists in faculties than at departments include pedagogical personal 
counselling for teachers and offering personnel training, while the work load of the part-time specialists at the departments include tasks through their main duties, such as teaching. There are also tasks that have small roles in the whole work load but do not promote the development of (web-based) teaching either - e.g. IT support.

Both types of support personnel, the developers at the faculties and the departmental contact persons, are needed to ensure both the e-learning viewpoint in the systematic development of teaching and learning, and the instant support in daily teaching routines. At the moment, the faculties at the University of Helsinki provide one of these two types of support: the network members are mostly one per faculty or one per department.

The group activities of the network have been formed during the current strategy period. The developmental needs and interests are worked out in brainstorms twice a year, after which the coordinator analyses the results and makes a proposition for the following period. The proposition is discussed with the members and published on the web-based working areas. The needs become concrete in group meetings and personnel training, and subjects for further development. The work is an ongoing, iterative process with academic term cycles, constant interaction between the coordinator and the network, using collaborative working methods. This activity of the network is coordinated at the Educational Centre for ICT, who is responsible for the training and support services in the use of ICT in teaching and for coordinating the development of online teaching at the University of Helsinki [3, page 94].

\subsection{The Network of Senior Lecturers in University Pedagogy}

Each of the faculties has one senior lecturer in university pedagogy. The members of the network are responsible for the systematic development of teaching and learning methods in their faculties. Also, their tasks include conducting research related to the field of university pedagogy. The senior lecturers provide courses in university pedagogy, and cooperate in various subject courses in their faculties. They form a network of expertise, discussing topical developmental challenges in education at the university level.

The Helsinki University Centre for Research and Development of Higher Education [7], a unit concentrating on the university pedagogical matters, acts in the cooperation with the senior lecturers in university pedagogy in matters of educational development. The centre is in charge of the degree programme of the studies in university pedagogy provided for the personnel and $\mathrm{PhD}$ students. The elementary course is organized regularly not only in the Centre but also on every campus area. These science-based university pedagogy courses offer the personnel an opportunity to identify and foster awareness and understanding of the special features of teaching and instruction approaches of the faculty disciplines.

In their faculties, the lecturers are also in charge of the curriculum development at a degree level, organizing and supporting study guidance. They participate in faculty strategic planning and implementing the strategy of the university in the disciplines of the departments. In some of the faculties, the senior lecturers in university pedagogy are heads of the research and development unit in higher education in their faculty, and all of them are leading pedagogical advisers and experts in their home faculties. 
The university has acted upon the recommendation from external evaluations by establishing and funding senior lecturers in pedagogy and encouraging the development of a particular centre for research and development of higher education. The present outcome of this development was highly appreciated by the panellists evaluating the leadership and management of education last year [5].

The university strategy focuses on the learner-centred approach [1]. This principle has been expanded to a teaching evaluation matrix, which is available universitywide. At the moment, an increasing number of academic teaching personnel has pedagogic training.

According to the recent international evaluators, the decision to locate senior lecturers in university pedagogy at the faculties is an excellent example of good practice at the university level [5].

\section{Structures and Methods for Organized and Goal-Oriented Collaboration}

\subsection{Organizational Support}

Many e-learning specialist network members named their educational development team and especially the senior lecturer in university pedagogy as the most important collaboration partners in the survey. In fact, those e-learning specialists, who work in faculties, work in teams and collaborate, and those who work at departments, do not have teams. In feedback discussions, the senior lecturers shared the same positive opinions of peer collaboration as the e-learning specialists. They emphasised the need for colleagues in everyday work in faculties not yet having a unit of pedagogical support. Most lecturers indicated that the peer network provides a valuable collegial environment enhancing further development.

In faculties with educational development teams, the collaboration between the specialists in e-learning and the senior lecturers in university pedagogy forms an essential part of the daily activities. For example, improving and developing the student feedback systems is one of the constant fields of collaboration of the specialists. Motivating the teaching personnel to modern working methods including web-based environments needs both effort and knowledge from the two collaborating experts. In many faculties the specialist in e-learning is co-operating with the lecturer in organising and teaching during the basic course in university pedagogy. Teacher cafés and other regular gatherings of the personnel are often organized by a group of these faculty experts.

"Campuses and faculties may establish their own units for developing and supporting teaching. The University will consolidate its common, centrally funded services in the long term, which will allow the faculties to create their own services and thus supplement the University-wide services as they wish.",

"Faculties and departments will work as teams to plan the production processes of online teaching. The faculties will implement online teaching more efficiently [...]" and

"The University will coordinate the provision of centralised support services for teaching on the campuses based on the faculties' target programmes and user needs." [3, pages 93-95] 
Most faculties at the University of Helsinki have the described team structure for the continuous and systematic educational development, but not all of them have built-in organisational units. We recommend, that the organisational structure is official with own budgeting, being positioned at the faculty office under the dean or vice dean responsible for educational matters, like presented in Figure 1. The team includes the senior lecturer as head and the e-learning specialist and teaching planning officers as members building a meaningful combination. Furthermore, we suggest that the departments have their part-time e-learning contact persons who collaborate with the faculty educational development team and especially with the e-learning specialist.

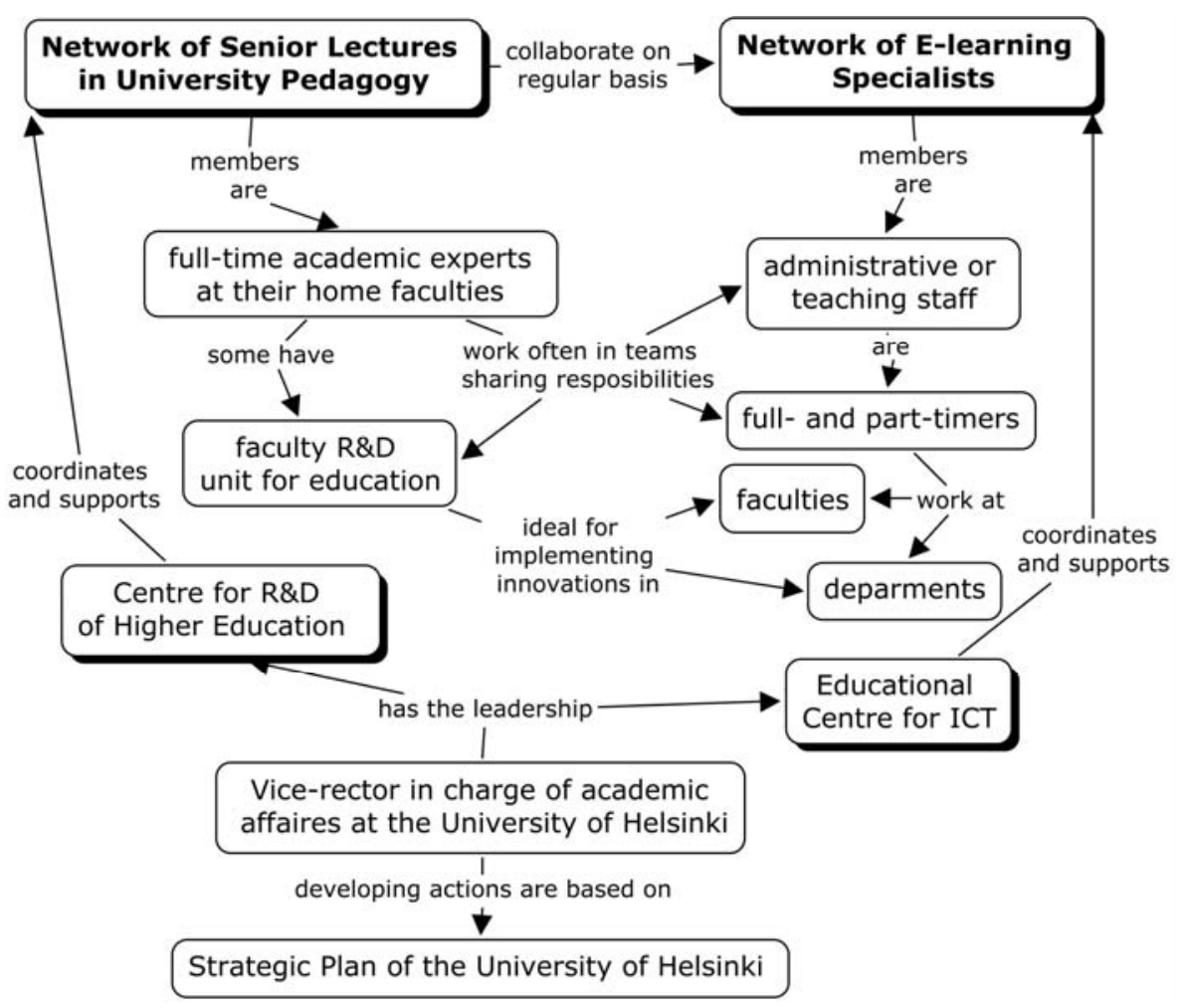

Fig. 1. Structures supporting collaboration at the University of Helsinki

\subsection{Peer Networking across the Organizational Structure}

The strength of both the e-learning specialist network and the senior lecturer network is considered being in networking to peers. The e-learning specialist network is considered active and the coordinator listens to the needs of the network. The activities support both the members' duties and professional development. Mailing lists, blog entries, micro blogging and instant messaging are actively used as information and discussion channels, the tool being selected based on the information contents and required audience. The information also reaches the designed audience. The network has used a wiki space for collaborative document processing. 
The contact networks, including both official cooperation partners and personal contacts, inside the university are available for and used by the specialists when needed. Interest for further contacts was mentioned to other national actors, such as corresponding support networks in other universities. Actually, this kind of supporting structure is quite unique in Finland. There is a national network, which consists of one contact person per university, but there has been almost no activity for some years now.

Since the field of educational technology is under constant development and there is a constant pressure for development of competences and awareness of peer competences, the role of the e-learning specialist network in peer support, learning and development is emphasized. The network is compared to a real-world safety net and the members to trapeze artists balancing on the wire; you can always count on the net, so you dare to try things that you otherwise would not dare. The e-learning specialist network members described the meaning of the peer collaboration in four different ways:

1) Backup; thank you for being there!

2) Increasing awareness on peer knowledge and skills, and contextual information about the university

3) knowledge and skills exchange in concrete support tasks and training

4) Peer discussion support in problematic situations, coping.

To make the increase in awareness, knowledge and skills possible, activities and discussions must be regular. To ensure both regularity and a meaningful goal-oriented scope in the activity, the networks must be coordinated. The coordinator listens to the network and, based on the needs, selects the topics and plans the contents for advanced and specified personnel training, using meaningful web-based collaboration tools for goal-oriented knowledge development of the network members. This coordination must be funded by university central means.

\subsection{Knowledge Transfer through Networking}

The knowledge gained through the peer network of expertise is transferred to the home organisations of the network members as best practices and ideas for (online) teaching. The information channels are either public like the blog or free for anyone to register to, like Skype and Yammer. Via the public, web-based knowledge repositories the knowledge of the members of the network is turned to knowledge of the whole network.

"[... The] educational technology advisors will support and participate in cooperation across faculty and university boundaries." and

"Cooperation in the provision of support services for the use of ICT in teaching will be intensified between the providers of centralised support services and faculties and other parties. The support service processes will be defined, and responsibilities and roles will be specified." [3, pages 95-96]

The e-learning specialists are central actors in their communities dominating and sharing knowledge on e-learning and educational technology [4]. To enhance the possibilities for the e-learning specialists to work across the university, we suggest that there are commonly agreed duties for the network members, like there are for the senior lecturers, and this university-wide collaboration is included in them. The e-learning 
specialists are at the moment employed by the faculties and departments, which naturally targets the duties to the organisation in question, while the senior lecturer salaries are paid by the university central administration though they work at the faculties.

\section{Future Perspectives}

The two collaborative networks of expertise, the e-learning specialists and the senior lecturers in university pedagogy, are examples of best practices for the development of teaching at university level, when they work at best. The continuous development processes have to be supported both vertically with organizational structures and horizontally with coordination of knowledge development in peer networks. The overall situation at the University of Helsinki at the end of the strategy period 2007-2009 is good but not systematically implemented through the structures with faculties and departments. The recommended structures are already there in most faculties, but not all.

The best practices of one of the networks could be implemented also in the other one. The e-learning specialists are coordinated for professional development and awareness increase and web-based environments supporting collaboration in the physically distributed network are actively in use. The senior lecturers are centrally funded and have commonly agreed duties including university-wide participation in the development of education.

As research is multidisciplinary, the university strategy aims at enhancing multidisciplinary collaboration also in teaching (Strategic plan of University of Helsinki, 2006). The two networks working with development of education are the key persons in making this strategic goal reality.

\section{References}

1. Biggs, J., Tang, C.: Teaching for Quality Learning at University, 3rd edn. The Society for Research into Higher Education. Open University Press, London (2007)

2. University of Helsinki in Brief. Helsinki, Helsinki University Print (2008), http: / / www.helsinki.fi/inbrief/inbrief.html (retrieved 2.4.2009)

3. Programme for the development of teaching and studies 2007-2009. Helsinki, Helsinki University Print, In English, pp. 71-102 (2006), http: / / www.helsinki.fi/opetus/materiaali/ Opetuksen\%20ja\%20opintojen\%20kehitt_ohjelma\%202007-2009.pdf (retrieved 9.2.2009)

4. Ryymin, E.: Teachers' Intelligent Networks. Study on Relationship-based Professional Development Supported by Collaborative Learning Technologies. PhD Thesis, Acta Electronica Universitatis Tamperensis 751 (2008),

http: / /acta.uta.fi/haekokoversio.php?id=11101 (retrieved 3.4.2009)

5. Saari, S., Frimodig, M. (eds.): Leadership and Management of Education. Evaluation of Education at the University of Helsinki 2007-2008. Administrative Publications 58, Evaluations. Helsinki University Print, Helsinki (2008)

6. Strategic Plan of the University of Helsinki 2007-2009. Helsinki University Print, In English, pp. 57-80 (2006),

http://www.helsinki.fi/tutkinnonuudistus/materiaalit/ strategia2007-2009.pdf (retrieved 3.4.2009).

7. The Helsinki University Centre for Research and Development of Higher Education (2009), http: / /www.helsinki.fi/ktl/yty/english/index.htm (retrieved 10.6.2009) 